\title{
MENINGKATKAN HASIL BELAJAR MATEMATIKA DENGAN BLENDED LEARNING DAN MOTIVASI BERPRESTASI SISWA
}

\author{
Nurdin Ibrahim \\ e-mail: nurdin1349@yahoo.com \\ Kurikulum dan Teknologi Pendidikan, FIP Universitas Negeri Jakarta
}

\begin{abstract}
Abstrak: Penelitian ini bertujuan untuk mengetahui hubungan antara pelaksanaan blended learning dan motivasi berprestasi dengan hasil belajar Matematika. Penelitian ini dilaksanakan di SMP Terbuka 2 Tanjung Priok, yang berinduk di SMP Negeri 55 Tanjung Priok, Jakarta Utara selama 2 bulan, sejak bulan Mei sampai dengan bulan Juni 2010. Penelitian ini menggunakan metode survei pendekatan statistik dengan uji korelasi. Masalah yang menjadi fokus penelitian adalah (a) apakah terdapat hubungan positif antara pelaksanaan blended learning (X1) dengan hasil belajar Matematika (Y), (b) apakah terdapat hubungan positif antara motivasi berprestasi (X2) dengan hasil belajar Matematika (Y), dan (c) apakah terdapat hubungan positif antara pelaksanaan blended learning (X1) dan motivasi berprestasi (X2) secara bersama-sama dengan hasil belajar Matematika (Y)? Hasil penelitian menunjukkan bahwa (a) terdapat hubungan positif antara pelaksanaan blended learning (X1) dengan hasil belajar Matematika; (b) terdapat hubungan positif antara motivasi berprestasi (X2) dengan hasil belajar Matematika, dan (c) terdapat hubungan positif antara pelaksanaan blended learning (X1) dan motivasi berprestasi (X2) secara bersamasama dengan hasil belajar Matematika.
\end{abstract}

Kata kunci: blended learning, motivasi berprestasi, hasil belajar

\section{IMPROVING LEARNING ACHIEVEMENT IN MATHEMATICS THROUGH BLENDED LEARNING AND STUDENT'S MOTIVATION}

\begin{abstract}
The purpose of this research was to know the correlation between the blended learning or achievement motivation and learning achievement. Taking place in Open Junior Secondary School, Tanjung Priuk, affiliated to State Junior Secondary School, No. 55, Tanjung Priuk, the research was conducted as from May through June 2010. The research used survey method with statistical approach and the research focus are (a) the correlation between blended learning and learning achievement, (b) the correlation between achievement motivation and learning achievement, and (c) the correlation between both of blended learning and achievement motivation and learning achievement simultanously. The research proved (a) the positive correlation between blended learning and learning achievement, (b) the positive correlation between achievement motivation and learning avhievement, and (c) the positive correlation between both of blended learning and achievement motivation and learning achievement simultanously. In addition to the findings, the research also provided some suggestions related to instructional process.
\end{abstract}

Keywords: blended learning, achievement motivation, learning achievement

\section{PENDAHULUAN}

SMP Terbuka merupakan salah satu model layanan pendidikan alternatif jalur sekolah tingkat SMP yang diselenggarakan oleh SMP reguler. Tetapi perlu diketahui bahwa SMP Terbuka bukanlah lembaga atau UPT baru yang berdiri sendiri, melainkan menginduk pada SMP reguler yang telah ada. SMP reguler yang menjadi induk tersebut menyelenggarakan pendidikan dengan modus dual system (sistem ganda), artinya sekaligus melayani dua kelompok siswa yang berbeda, dengan cara belajar yang berbeda. SMP penyelenggara SMP Terbuka pada dasarnya perluasan atau penambahan peran, berupa layanan pendidikan dengan sistem terbuka jarak jauh yang diperuntukkan bagi siswa yang memiliki kendala tertentu, misalnya membantu orang tua bekerja pada waktu sekolah secara reguler. Untuk mencapai tujuan pendidikan yang berkualitas diperlukan pengelolaan pendidikan yang dapat memobilisasi segala sumber daya yang isinya memberikan motivasi dan perencanaan model pembelajaran. Pemikiran ini didasari oleh telah banyak penelitian-penelitian yang dilakukan menunjukkan adanya hubungan yang cukup signifikan antara motivasi berprestasi dan teknik pendekatan belajar dengan prestasi belajar khususnya IPA Fisika dan matematika (Ibrahim, 2001). Atas dasar hal tersebut, Direktorat Pembinaan SMP merintis program pem- 
belajaran berbasis blended learning, yang dimulai pada 2008/2009 di tiga lokasi SMP Terbuka, yaitu SMP Terbuka 2 Tanjung Priok, Jakarta Utara, SMP Terbuka Kandanghaur Indramayu, Jawa Barat, dan SMP Terbuka 1 Kota Malang, Jawa Timur. Untuk menunjang program tersebut, pada masing-masing SMP Terbuka dkembangkan satu laboratorium komputer, dengan 40 buah notebook yang terkoneksi ke website Direktorat Pembinaan SMP dan atau Jardiknas di Pustekkom Kemdiknas. Dengan demikian, siswa-siswa SMP Terbuka dapat meningkatkan sistem belajar mandiri atau kelompok dengan pendekatan blended learning.

Model blended learning pada dasarnya mengkombinasikan keunggulan berbagai teknik pembelajaran dalam penyelenggaraan Pendidikan Jarak Jauh (PJJ). Menurut Semler (2005), blended learning combines the beast aspects of online learning, structured face-to-face activities and read world practice. Online learning systems, classroom training, and on-the-job experience have major drawbacks by themselves. The blended learing approach uses the strengths of each to counter the aorther's weaknesses.

Dalam artikelnya, McGinnis (2005) menyarankan ada enam hal yang perlu diperhatikan manakala menyelenggarakan blended learning yakni: (1) penyampaian bahan ajar dan penyampaian pesan-pesan yang lain secara konsisten (contoh: pengumuman yang berkaitan dengan kebijakan atau aturan); (2) penyelenggaraan blended learning harus dilaksanakan secara serius. Hal ini akan mendorong siswa cepat menyesuaikan diri dengan sistem PJJ untuk lebih cepat mandiri; (3) bahan ajar yang diberikan harus mengalami perbaikan, baik dari sisi format maupun isi, (4) alokasi waktu bisa dimulai dengan formula awal 75:25, 75\% waktu digunakan untuk pembelajaran online dan $25 \%$ digunakan secara tatap muka, (5) alokasi tutorial 25\% digunakan untuk mereka yang tertinggal; dan (6) dalam blended learning diperlukan kepemimpinan yang mempunyai waktu dan perhatian untuk terus berupaya bagaimana mmeningkatkan kualitas pembelajaran.

Oleh sebab itu, proses pembelajaran konvensional secara bertahap harus memanfaatkan media dan multimedia, agar lebih berkualitas. Perkembangan ilmu pengetahuan dan teknologi yang semakin maju pesat menuntut tersedianya media dan multimedia yang menunjang pembelajaran di kelas maupun dalam pembelajaran mandiri.

Menurut Wittrock (dalam Good dan Brophy, 1990: 124), belajar adalah suatu terminologi yang menggambarkan suatu proses perubahan melalui pengalaman. Proses tersebut mempersyaratkan perubahan yang relatif permanen berupa sikap, penge- tahuan, informasi, kemampuan, dan keterampilan melalui pengalaman. Berarti belajar itu menghasilkan berbagai macam tingkah laku yang berlain-lainan, seperti pengetahuan, sikap, keterampilan, kemampuan, informasi, dan nilai. Berbagai macam tingkah laku yang berlainan inilah yang disebut kababilitas sebagai hasil belajar. Selanjutnya Good \& Brophy (1990: 124) mengatakan bahwa belajar itu bagaimana seseorang memanipulasi lingkungan.

Pengertian dan konsepsi hasil belajar yang dikemukakan oleh ahli-ahli, sedikit banyak dipengaruhi oleh aliran-aliran atau teori-teori yang dianutnya. Skiner dengan teori Kondisioning Operannya sebagaimana dikutip Gredler (1991: 172) mengatakan bahwa hasil belajar merupakan respon (tingkah laku) yang baru. Walaupun Skiner mengatakan bahwa hasil belajar adalah berupa "respon yang baru", namun pada dasarnya respon yang baru itu sama pengertiannya dengan tingkah laku (pengetahuan, sikap, keterampilan) yang baru.

Gagne \& Briggs membagi hasil belajar menjadi lima kategori kapabilitas, yaitu (1) keterampilan intelektual (intellectual skills), (2) strategi kognitif (cognitive strategies), (3) informasi verbal (verbal information), (4) keterampilan motorik (motor skills), dan (5) sikap (attitudes). Keterampilan intelektual adalah kecakapan yang berkenaan dengan pengetahuan prosedural, mulai dari kemampuan membedakan, konsep konkret, konsep definisi, kaidah serta kaidah yang lebih tinggi; kaidah yang mengandung banyak langkah disebut prosedur (Gagne, 1989:90).

Bloom dkk (1956), sebagaimana dikutip oleh Degeng (1989: 176-177), mengklasifikasikan hasil belajar menjadi tiga domain atau ranah, yaitu ranah kognitif, psikomotor, dan sikap. Ranah kognitif menaruh perhatian pada pengembangan kapabilitas dan keterampilan intelektual; ranah psikomotor berkaitan dengan kegiatan-kegiatan manipulatif atau keterampilan motorik; dan ranah sikap berkaitan dengan pengembangan perasaan, sikap, nilai, dan emosi.

Reigeluth (1983:20) mengatakan bahwa hasil pembelajaran secara umum dapat dikategorisasi menjadi tiga domain, yaitu (1) keefektifitas pembelajaran, yang biasanya diukur dari tingkat keberhasilan (prestasi) siswa dari berbagai sudut; (2) efisiensi pembelajaran, yang biasanya diukur dari waktu belajar dan/atau biaya pembelajaran; dan (3) daya tarik pembelajaran yang selalu diukur dari tendensi siswa ingin belajar secara kontinu. Secara spesifik, hasil belajar adalah suatu kinerja (performance) yang diindikasikan sebagai suatu kapabilitas (kemampuan) yang telah diperoleh. Kategori hasil belajar seperti di atas berlaku 
bagi semua mata pelajaran pada setiap satuan dan tingkat pendidikan, misalnya pada SMP Terbuka di antaranya pendidikan Sains (IPA Fisika dan Biologi), Bahasa Inggris, dan Pendidikan Matematika.

Berdasarkan hasil pemantauan (Direktorat Pembinaan SMP, 2007, 2008, 2009) dan hasil penelitian (Ibrahim, 1997) mata pelajaran yang dianggap sulit bagi siswa SMP Terbuka meliputi: Bahasa Inggris, IPA Fisika, Bahasa Indonesia, dan Matematik. Salah satu kendala yang dialami pendidikan SMP terbuka adalah rendahnya prestasi matematika siswa. Hal ini merupakan suatu tantangan bagi penyelenggaran pendidikan sistem SMP Terbuka

Pendidikan Matematika merupakan salah satu mata pelajaran utama baik ditingkat SD, SMP, SMA. Matematika adalah ilmu deduktif, aksiomatik, formal, hirarkis, abstrak, dan bahasa simbol yang padat arti. Pola berpikir siswa sangat bervariasi dalam tahapan dari konkret ke pemikiran abstrak. Keberadaan Matematika sangat berguna bagi siswa untuk bekal hidup di dalam mempelajari ilmu-ilmu yang akan dipelajari kelak pada tingkatan di atasnya (Karso, 2004: 128).

Kamus Besar Bahasa Indonesia menyatakan bahwa Matematika adalah ilmu tentang bilanganbilangan, hubungan antara bilangan, dan prosedur operasional yang digunakan dalam penyelesaian masalah-masalah mengenai bilangan. Kegiatan pembelajaran di pendidikan dasar, khususnya pendidikan Matematika umumnya masih mempelajari bilanganbilangan, hubungan antara bilangan dan prosedur operasional bilangan-bilangan dalam menyelesaikan masalah-masalah dalam kehidupan sehari-sehari. Pengetahuan tentang hubungan antara bilangan dan operasi bilangan pada pendidikan dasar (SD dan SMP) sangat berguna untuk memecahkan masalah-masalah perhitungan pada level pendidikan yang lebih tinggi, seperti di level SMA, SMK, Perguruan Tinggi, bahkan dalam Tes Potensi Akademik (TPA) ketika seseorang mengikuti pendidikan di Perguruan Tinggi ataupun masuk pegawai khususnya pegawai negeri. Konsep ini sesuai dengan konsep tahapan hasil belajar strategi kognitif dan keterampilan intelektual dari Gagne \& Briggs (1989: 91-93). Pembelajaran tentang bilangan dan prosedur penggunaan serta pengoperasional bilangan untuk memecahkan masalah kehidupan, selaras dengan kemampuan aplikasi dalam ranah kognitif dari Bloom dkk.

Kegiatan pembelajaran di sekolah akan berlangsung dengan baik apabila ada interaksi antara guru dengan siswa, siswa dengan siswa, siswa dengan kelompoknya, dan antara siswa dengan sumber belajar.
Oleh karena itu, siswa dituntut untuk bersikap aktif, kreatif, dan inovatif dalam memecahkan masalahmasalah pembelajaran khususnya Matematika. Sikap aktif, kreatif, dan inovatif terwujud dengan menempatkan siswa sebagai subjek pendidikan, siswa diberi kebebasan untuk mencari informasi-informasi dari berbagai sumber belajar, baik secara perorangan ataupun berkelompok. Untuk menopang kebebasan siswa tersebut, sekolah hendaknya menciptakan suasana atau kondisi lingkungan pembelajaran yang efektif dan efisien, serta dapat menciptakan daya tarik pembelajaran. Ketiga kondisi tersebut sesuai dengan konsep hasil pembelajaran sebagaimana yang diungkapkan oleh Reigeluth (1983). Ini berarti apabila tercipta kondisi lingkungan pembelajaran yang dimaksud tersebut maka hasil belajar siswa akan lebih baik.

Dalam kurikulum berbasis kompetensi, disebutkan pembelajaran Matematika di sekolah berfungsi mengembangkan kemampuan berkomunikasi dengan menggunakan bilangan dan simbol-simbol serta ketajaman penalaran yang dapat membantu memperjelas dalam menyelesaikan berbagai permasalahan kehidupan sehari-hari. Pembelajaran Matematika di sekolah dapat bermanfaat untuk membantu pola pikir matematis yang sistematis, logis, kritis, dan dengan penuh kecermatan.

Untuk menumbuhkan sikap aktif, kreatif, inovatif, dan pola pikir matematis yang sistematis, logis, serta kritis dari siswa bukanlah hal yang mudah. Fakta di lapangan, proses pembelajaran yang terjadi memposisikan siswa sebagai pendengar ceramah guru. Akibatnya proses pembelajaran cenderung membosankan, tidak efektif dan efisien yang pada akhirnya menjadikan siswa malas belajar. Oleh karena itu, perlu dicarikan solusi pemecahan agar pembelajaran Matematika dapat dimengerti, dipahami, oleh siswa melalui upaya perbaikan seperti meningkatkan peran dan kompetensi guru dalam proses pembelajaran, guru yang berkompetensi dapat menciptakan lingkungan belajar yang efektif, efisien, dan menarik serta mampu mengelola kelasnya sehingga dapat meningkatkan hasil belajar siswa pada tingkat optimal.

Dalam menyampaikan materi pembelajaran, guru dituntut untuk menggunakan model pembelajaran yang efektif, efisien, dan menarik, yang salah satunya adalah blended learning. Dengan model pembelajaran blended learning siswa SMP Terbuka dapat memanfaatkan internet di laboratorium komputer sekolah, baik secara mandiri maupun kelompok. Dengan demikian, intensitas belajar mandiri dengan berbagi sumber belajar dapat ditingkatkan. Tentu untuk kegiatan belajar mandiri di laboratorium komputer 
sekolah perlu ada guru bina Matematik sebagai fasilitator. Dengan model pembelajaran berbasis teknologi informasi dan komunikasi ini diharapkan siswa SMP Terbuka mampu memberikan solusi dari berbagai kendala dalam menanggapi kesulitan belajar mereka.

Dalam pembelajaran Matematika dibutuhkan banyak latihan. Penerapan blended learning, juga melatih siswa agar terbiasa berusaha menghadapi tugas-tugas mata pelajaran Matematika yang harus diselesaikan dengan memanfaatkan TIK untuk mencari informasi-informasi pembelajaran Matematika yang berguna untuk memecahkan masalah kesulitan dalam belajar mandiri.

Faktor lain yang menjadi pertimbangan menurunnya prestasi hasil belajar matematika adalah motivasi siswa untuk berprestasi. Motivasi berprestasi sebagai kebutuhan untuk berprestasi (Need for Achievement or $n$ Ach) sebagai keinginan atau kecenderungan untuk mengatasi hambatan, menguji kekuatan, sekuat tenaga melakukan sesuatu yang sulit sebaik dan secepat mungkin (Beck at al, 1983). Hal ini menunjukkan bahwa motivasi berprestasi adalah keinginan atau kecenderungan untuk mengatasi hambatan, menguji kekuatan, sekuat tenaga melakukan sesuatu yang sulit sebaik dan secepat mungkin untuk mencapai tujuan.

Motivasi berprestasi merupakan produk dari dua kebutuhan yang bertentangan, yaitu: kebutuhan untuk mencapai kesuksesan dan kebutuhan untuk menghindari kegagalan (Beck at al, 1983) . Berdasarkan definisi yang dikembangkan Elliot \& Church (2001) bahwa motivasi berprestasi sebagai usaha keras untuk mendapatkan kemampuan yang relevan dengan kehidupan sehari-hari pada tempat kerja, sekolah atau perlombaan, serta mengembangkan suatu model yang disebut Hierarchical Model of Approach and Avoidance Achievement Motivation.

Konsep yang lebih komprehensif tentang motivasi berprestasi selanjutnya dikembangkan oleh Atkinson (Good \& Brophy, 1990), dengan Teori Motivasi Berprestasi. Teori ini menyatakan bahwa kecenderungan mendekati tujuan (Ts) adalah hasil dari tiga faktor, yaitu: hasrat untuk berprestasi atau motivasi sukses (Ms); kemungkinan untuk sukses (Ps) dan nilai kemudahan untuk sukses (Is). Ketiga faktor tersebut merupakan faktor yang paling inheren dalam motivasi berprestasi.

Ciri-ciri individu yang memiliki motivasi berprestasi tinggi, yaitu: lebih gigih dalam mencapai tujuan, realistis dalam menilai kemampuan diri sendiri dan lingkungan, serta mengutamakan tindakan bila dibandingkan dengan individu yang memiliki latar belakang motivasi lain (Edward, 1997).
Motivasi berprestasi adalah upaya keras untuk mendapatkan kemampuan yang relevan dengan kehidupan sehari-hari yang dapat dilihat dari kegigihan, realistis dalam memilih dan mengutamakan tindakan. Berdasarkan uraian tersebut, bahwa untuk mewujudkan pendidikan yang bermutu dan efisien, efektif, dan menarik perlu disusun dan dilaksanakan programprogram pendidikan yang mampu membelajarkan peserta didik secara berkelanjutan, karena dengan kualitas pendidikan yang optimal, diharapkan akan dicapai keunggulan sumber daya manusia yang dapat menguasai pengetahuan, keterampilan, dan keahlian sesuai dengan ilmu pengetahuan dan teknologi yang terus berkembang. Dengan demikian, diduga terdapat pengaruh model pembelajaran blended learning dan motivasi berprestasi, baik secara sendiri-sendiri maupun secara simultan terhadap prestasi hasil belajar matematika.

\section{Rumusan Masalah}

Permasalahan yang diteliti dalam penelitian ini adalah: (1) Apakah terdapat hubungan positif antara pelaksanaan Blanded learning (X1) dengan hasil belajar Matematika (Y)? (2) Apakah terdapat hubungan positif antara motivasi berprestasi (X2) dengan hasil belajar Matematika (Y)? (3) Apakah terdapat hubungan positif antara pelaksanaan Blanded learning (X1) dan motivasi berprestasi (X2) secara bersama-sama dengan hasil belajar Matematika (Y)?

\section{METODE PENELITIAN}

\section{Jenis Penelitian}

Dilihat dari paradigmanya, penelitian ini termasuk dalam penelitian positivistik atau penelitian kuantitatif. Penelitian ini menggunakan metode survei dengan pendekatan statistik deskriptif untuk mendeskripsi hal-hal yang berkaitan dengan motivasi berprestasi, blended learning dan hasil belajar Pendidikan Matematika serta menggunakan pendekatan inferensial untuk melihat hubungan motivasi berprestasi dengan hasil belajar Pendidikan Matematika, hubungan blended learning dengan prestasi hasil belajar Pendidikan Matematika, dan hubungan motivasi berprestasi dan blended learning secara bersama-sama dengan prestasi hasil belajar Pendidikan Matematika.

\section{Tempat dan Waktu Penelitian}

Penelitian ini dilaksanakan di SMP Terbuka 2, Tanjung Priok Jakarta Utara, selama 2 bulan sejak bulan Mei 2010 sampai dengan bulan Juni 2010.

\section{Prosedur Penelitian}

a. Sumber Data

Populasi penelitian adalah semua siswa SMP 
Terbuka kelas VII, VIII, dan Kelas IX, dengan sampel penelitian yang diambil dengan purposif sederhana sejumlah 30 siswa SMP Terbuka kelas VII. 30 orang siswa yang dipilih terdiri dari 10 orang siswa bermotivasi berprestasi tinggi, 10 orang siswa bermotivasi berprestasi sedang, dan 10 orang siswa bermotivasi berprestasi rendah. Penentuan pengelompokan tersebut didasarkan pada tes motivasi berprestasi.

b. Teknik Pengumpulan Data

Instrumen yang digunakan untuk mengumpulkan data penelitian ini dalam bentuk kuesioner, meliputi kuesioner motivasi berprestasi dan blended learning, sedangkan hasil belajar matematik diambil dari prestasi belajar ulangan akhir semester dua Pendidikan Matematika tahun pelajaran 2010. Sebelum digunakan untuk pengumpulan data, instrumen penelitian terlebih dahulu dilakukan uji validitas dan reliabilitas.

Kuesioner blended learning dan motivasi berprestasi, uji validitas dilakukan dengan Product Moment Validity, sedangkan untuk uji reliabilitas menggunakan Grounbach Alpha. Sementara itu, untuk instrumen tes prestasi belajar Pendidikan Matematika, tidak dilakukan uji validitas dan reliabilitas, dengan alasan item tesnya dianggap telah valid karena disusun oleh tim yang dibentuk oleh Kepala Suku Dinas Pendidikan Wilayah Jakarta Utara. Instrumen tes yang dikembangkan oleh tim tersebut digunakan untuk ujian akhir semester bagi kelas VII SMP seluruh wilayah Jakarta Utara. Diasumsikan sebelum digunakan dalam ujian akhir semester, instrumen tes tersebut telah diuji cobakan secara empirik.

c. Teknik Analisis Data

Analisis data dilakukan dengan menggunakan teknik analisis korelasi regresi bivariat dan multiple regresi dengan menggunakan program SPSS versi 18.

\section{HASIL DAN PEMBAHASAN}

\section{Hasil Penelitian}

Hasil deskripsi data nilai prestasi hasil belajar matematikan menunjukkan 33,33\% siswa masuk pada kategori kelompok rendah atau di bawah skor rata-rata, 26,67 \% siswa masuk pada kategori kelompok ratarata, dan $40 \%$ siswa masuk pada kategori kelompok tinggi atau di atas rata-rata. Hal ini menunjukkan skor prestasi hasil belajar matematika yang paling banyak dicapai berada pada kisaran nilai 69-80, yaitu dengan frekuensi absolut 12 responden. Artinya, prestasi hasil belajar matematika siswa SMP Terbuka cukup tinggi, hal ini ditandai dengan rasio antara kategori rendah dan kategori rata-rata ditambah dengan di atas ratarata $(33,33: 66,77)$.
Nilai motivasi berprestasi menunjukkan 30\% siswa masuk pada kategori kelompok rendah atau di bawah skor rata-rata, 26,67\% siswa masuk pada kategori kelompok rata-rata, dan 43,33\% siswa masuk pada kategori kelompok tinggi atau di atas rata-rata. Hal ini menunjukkan skor motivasi berprestasi yang paling banyak dicapai berada pada kisaran nilai skor 145-163, yaitu dengan frekuensi absolut 21. Artinya motivasi berprestasi cukup tinggi, hal ini ditandai dengan rasio antara kategori rendah dan kategori rata-rata ditambah dengan di atas rata-rata (30:70).

Sementara itu nilai skor blended learning menunjukkan 46,67\% siswa masuk pada kategori kelompok rendah atau di bawah skor rata-rata, 13,33\% siswa masuk pada kategori kelompok rata-rata, dan $40 \%$ siswa masuk pada kategori kelompok tinggi atau di atas rata-rata. Hal ini menunjukkan nilai skor blended learning yang paling banyak dicapai berada pada kisaran nilai skor 68-79, yaitu dengan frekuensi absolut 16 responden, artinya program pembelajaran blended learning cukup baik, hal ini ditandai dengan rasio antara kategori rendah dan kategori rata-rata ditambah dengan di atas rata-rata $(46,67: 53,33)$.

1. Hubungan Antara Motivasi Berprestasi dengan Hasil Belajar Matematika

Berdasarkan hasil Uji hubungan motivasi berprestasi dengan hasil belajar matematika menghasilkan persamaan regresi $Y=6,938+0,419 X 1$. Selanjutnya diperoleh nilai $F_{\text {hitung }}$ uji signifikansi persamaan regresi sebesar 23,61 pada taraf signifikansi 0,05 . Nilai $\mathrm{F}_{\text {hitung }}$ untuk linearitas diperoleh sebesar 1,112 $<\mathrm{F}_{\text {tabel }}$ 3,44, untuk jelas dapat dilhat pada Tabel 1 .

Tabel 1. Analisis Varians (ANAVA) Untuk Uji Signifikansi dan Linieritas Regresi $Y=6,938+0,419 X_{1}$

\begin{tabular}{|c|c|c|c|c|c|c|}
\hline \multirow{2}{*}{ Sumber Variasi } & \multirow{2}{*}{$\mathrm{dk}$} & \multirow{2}{*}{ JK } & \multirow{2}{*}{ RJK } & \multirow{2}{*}{ F hitung } & \multicolumn{2}{|c|}{ F tabel } \\
\hline & & & & & $\alpha 0.05$ & $\alpha .0 .01$ \\
\hline Total Reduksi & 29 & 945,467 & & & & \\
\hline $\begin{array}{l}\text { Regresi }(\mathrm{b} \mid \mathrm{a}) \\
\text { Sisa }\end{array}$ & $\begin{array}{c}1 \\
28\end{array}$ & $\begin{array}{l}432,537 \\
512,930\end{array}$ & $\begin{array}{c}432,537 \\
18,319\end{array}$ & $23,611^{* *}$ & 4,20 & 7,64 \\
\hline $\begin{array}{l}\text { Tuna Cocok } \\
\text { Galat }\end{array}$ & $\begin{array}{c}21 \\
7\end{array}$ & $\begin{array}{l}426,798 \\
122,667\end{array}$ & $\begin{array}{l}23,711 \\
12,267\end{array}$ & $1,122 \mathrm{~ns}$ & 3,42 & 6,13 \\
\hline 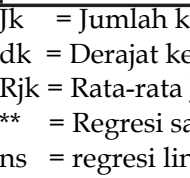 & $\begin{array}{l}\text { iadr } \\
\text { oeba } \\
\text { uml } \\
\text { ngat } \\
\text { ear ( }\end{array}$ & $\begin{array}{l}\text { n } \\
\text { kuadr } \\
\text { gnifika } \\
l=1,12\end{array}$ & $\begin{array}{l}(\mathrm{Fh}= \\
<\mathrm{Ft}=\end{array}$ & $\begin{array}{l}611>\mathrm{F} \\
42)\end{array}$ & $7,64)$ & \\
\hline
\end{tabular}

Sementara itu besar koefisien korelasi sebesar 0,419, sedangkan besar koefisien determinasi motivasi berpreatasi terhadap hasil belajar matematika adalah sebesar 0,457 atau 45,7\%, sedangkan sisanya 54,3\% 
dipengaruhi oleh variabel lain.

2. Hubungan Antara Blended Learning dengan Hasil Belajar Matematika

Selanjutnya berdasarkan uji hubungan blended learning dengan hasil belajar matematika diperoleh persamaan regresi $\mathrm{Y}=29,806+0,551 \mathrm{X}_{2}$. Perhitungan persamaan regresi diperoleh nilai $\mathrm{F}_{\text {hitung }}$ sebesar 20,18, sedangkan nilai $\mathrm{F}_{\text {tabel }}$ dengan $\mathrm{dk}$ pembilang $1 \mathrm{dan} \mathrm{dk}$ penyebut 28 pada taraf signifikasi 0,01 sebesar 7,64. seperti yang diperlihatkan tabel 2.

Tabel 2. Analisis Varians (ANAVA) Untuk Uji Signifikansi dan Linieritas Regresi $\mathrm{Y}=29,806+0,551 \mathrm{X} 2$

\begin{tabular}{|l|c|c|c|c|c|c|}
\hline \multirow{2}{*}{ Sumber Variasi } & \multirow{2}{*}{ dk } & \multirow{2}{*}{ JK } & \multirow{2}{*}{ RJK } & \multirow{2}{*}{ F hitung } & \multicolumn{2}{|c|}{ F tabel } \\
\cline { 5 - 7 } & & & & & $\alpha 0.05$ & $\alpha 0.01$ \\
\hline Total Reduksi & 29 & 945,467 & & & & \\
\hline Regresi (b|a) & 1 & 396,002 & 396,002 & $20,180^{* *}$ & 4,20 & 7,64 \\
Sisa & 28 & 549,465 & 19.624 & & & \\
\hline Tuna Cocok & 18 & 426,798 & 23,711 & $1,933 \mathrm{~ns}$ & 2,80 & 4,49 \\
Galat & 10 & 122,667 & 12,267 & & & \\
\hline
\end{tabular}

$\mathrm{Jk}=$ Jumlah kuadrat

$\mathrm{dk}=$ Derajat kebebasan

Rjk = Rata-rata Jumlah kuadrat

** $=$ Regresi sangat signifikan $(\mathrm{Fh}=20,180>\mathrm{Ft}=7,64)$

$\mathrm{ns}=$ regresi linear $(\mathrm{Fh}=1,933<\mathrm{Ft}=2,80)$

Dari tabel di atas, ternyata nilai $\mathrm{F}_{\text {hitung }}$ lebih besar dari nilai $\mathrm{F}_{\text {tabel }}$, maka dapat disimpulkan bahwa koefisien arah regresi $Y$ atas $X_{2}$ adalah "sangat signifikan" pada taraf signifikansi 0,001. Sedangkan nilai $\mathrm{F}_{\text {hitung }}$ linearitas hasil perhitungan diperoleh sebesar 1,93, sedangkan nilai $\mathrm{F}_{\text {tabel }}$ dengan dk pembilang 18 dan dk penyebut 10 pada taraf signifikansi 0,05 sebesar 2,79. Ternyata nilai $F_{\text {hitung }}$ lebih kecil dari nilai $F$, maka dapat disimpulkan bahwa bentuk regresi $Y$ atas $X_{2}$ adalah "linear", dengan koefisien korelasi sebesar 0,647 . Sementara itu besar koefisien determinasi blended learning terhadap hasil belajar matematika adalah sebesar 0,419 atau 41,9\%, sedangkan sisanya $58,1 \%$ dipengaruhi oleh variabel lain.

3. Uji Hubungan Motivasi Berprestasi dan Blended Learning dengan Hasil Belajar Matematika

Tabel 3. Analisis Varians (ANAVA) Untuk Regresi Ganda $\mathrm{Y}=4,380+0,328 \mathrm{X} 1+0,281 \mathrm{X} 2$

\begin{tabular}{|l|c|c|c|c|c|c|}
\hline \multirow{2}{*}{ Sumber Variasi } & \multirow{2}{*}{ dk } & \multirow{2}{*}{ JK } & \multirow{2}{*}{ RJK } & \multirow{2}{*}{ F hitung } & \multicolumn{2}{|c|}{ F tabel } \\
\cline { 6 - 7 } & & & & & $\alpha 0.05$ & $\alpha 0.01$ \\
\hline Total Reduksi & 29 & 945,467 & & & & \\
\hline $\begin{array}{l}\text { Regresi (b } \mid a) \\
\text { Sisa }\end{array}$ & 1 & 526,380 & 263,190 & $16,956^{*}$ & 4,74 & 9,55 \\
\hline
\end{tabular}

** regresi sangat signifikan pada a $=0,01$

Uji hubungan motivasi berprestasi dan blended learning secara bersama-sama dengan hasil belajar matematika diperoleh nilai $\mathrm{F}_{\text {hitung }}$ uji signifikansi persamaan regresi sebesar 24,775 pada taraf signifikansi 0,05 seperti yang disajikan pada tabel 3 .

Dengan demikian dapat disimpulkan bahwa koefisien arah regresi $Y$ atas $X_{2}$ adalah "sangat signifikan" pada taraf signifikansi 0,001. Dan hubungan koefisien korelasi ganda sebesar 0,746. Dapat diartikan bahwa hubungan motivasi berprestasi dan blended learning memiliki hubungan positif dan signifikan dengan prestasi hasil belajar matematika. Selain itu diketahui pula bahwa motivasi berprestasi dan blended learning secara bersama-sama memberikan sumbangan sebesar 55,6\% terhadap prestasi hasil belajar matematika, dengan demikian kontribusi variabel motivasi berprestasi dan blended learning secara bersama-sama terhadap hasil belajar matematika tergolong sangat berarti.

\section{Pembahasan}

Hasil deskripsi data nilai prestasi hasil belajar matematikan yang diperoleh dalam penelitian ini menunjukkan adanya perbedaan hasil tes prestasi buatan guru mata pelajaran (MGMP) dengan tes buatan peneliti yang tingkat daya beda dan tingkat kesukaran soal telah dilakukan sebelum diberikan kepada responden. Perbedaan hasil tes prestasi belajar matematika ini bisa terjadi kalau tes yang diberikan oleh guru tidak melalui pelaksanaan uji coba dalam hal mengetahui tentang daya beda dan tingkat kesukaran soal untuk siswa yang memiliki kemampuan yang bervariasi.

Hasil nilai skor motivasi berprestasi yang diperoleh berdasarkan nilai rata-rata empirik menunjukkan bahwa siswa SMP Terbuka 2 memiliki motivasi berprestasi tinggi untuk mengikuti pembelajaran matematika karena sebagian besar siswa memilih berusaha untuk menyelesaikan tugas, baik tugas rumah maupun soal-soal yang diberikan oleh guru untuk dikerjakan langsung di kelas, dan mereka berusaha menjawab dengan sungguh-sungguh dan hasilnya $72 \%$ dapat dijawab dengan benar.

Hasil nilai skor blended learning $\left(\mathrm{X}_{2}\right)$ yang diperoleh berdasarkan nilai rata-rata empirik menunjukkan bahwa proses belajar siswa SMP Terbuka 2 dengan program blended learning adalah sangat mendukung prestasi belajar matematika (Y) karena sebagian besar siswa memilih berusaha untuk menyelesaikan tugas baik tugas rumah maupun soal-soal yang diberikan oleh guru untuk dikerjakan langsung dikelas, dan mereka berusaha menjawab dengan sungguh-sungguh dan hasilnya $72 \%$ dapat dijawab dengan benar. Dengan kata lain, semakin sering siswa mengerjakan tugas dan rajin mencari informasi dari 
internet yang berkaitan dengan materi pembelajaran matematika, maka semakin tinggi kemampuan siswa menyelesaikan soal-soal tugas maupun tes akhir semester.

Hasil penelitian menunjukkan bahwa motivasi berprestasi $\left(X_{1}\right)$ mempunyai hubungan positif dengan hasil belajar matematika (Y) dengan kontribusi atau sumbangan variabel $X_{1}$ terhadap variabel $Y$ adalah sebesar $45,7 \%$. Hal ini menunjukkan bahwa motivasi berprestasi memberikan sumbangan yang cukup dan secara konsisten berhubungan searah dengan prestasi belajar matematika siswa $(\mathrm{Y})$. Dengan demikian, makin tinggi motivasi berprestasi siswa makin tinggi pula hasil belajar matematika siswa.

Blended learning $\left(\mathrm{X}_{2}\right)$ mempunyai hubungan positif dengan hasil belajar matematika $(Y)$. Dengan sumbangan sebesar $41,9 \%$, berarti variabel blended learning $\left(\mathrm{X}_{2}\right)$ secara konsisten berhubungan searah dengan hasil belajar matematika siswa (Y). Dengan demikian, makin tinggi blended learning siswa, makin tinggi pula hasil belajar matematika siswa.

Penelitian ini menemukan hubungan positif antara motivasi berprestasi (X1) dan blended learning secara bersama-sama dengan hasil belajar matematika (Y), dengan kontribusi atau sumbangannya adalah sebesar 55,7\%, sedangkan sisanya sebesar $44,3 \%$ ditentukan oleh variabel yang lain yang tidak masuk dalam penelitian ini.

Berdasarkan peringkat besar kekuatan hubungan, di mana kekuatan hubungan motivasi berprestasi dengan hasil belajar matematika siswa menempati peringkat pertama dan hubungan blended learning dengan hasil belajar matematika siswa menempati peringkat kedua. Artinya, kekuatan hubungan antara motivasi berprestasi dengan hasil belajar matematika siswa lebih kuat dibandingkan kekuatan hubungan blended learning dengan hasil belajar matematika siswa.

\section{PENUTUP}

\section{Kesimpulan}

Pembelajaran yang baik dan menarik akan mempengaruhi motivasi berprestasi dalam belajar siswa, sehingga pada akhirnya meningkatkan hasil belajar mereka. Terutama sekali dalam belajar mandiri pada siswa-siswa SMP Terbuka pada umumnya dan siswa SMP Terbuka 2 Tanjung Priok khususnya. Berdasarkan hasil penelitian di atas dapat disimpulkan bahwa: Pertama, ada hubungan positif antara motivasi berprestasi dengan hasil belajar matematika siswa SMP Terbuka 2 Tanjung Priok. Oleh karena itu, dapat dikatakan bahwa hasil belajar Matematika siswa SMP Terbuka Tanjung Priok salah satu faktornya disokong oleh motivasi berprestasi dalam belajar.

Kedua, ada hubungan positif antara blended learning dengan hasil belajar matematika siswa SMP Terbuka 2 Tanjung Priok. Oleh karena itu dapat dikatakan bahwa hasil belajar Matematika siswa SMP Terbuka Tanjung Priok salah satu faktornya disokong oleh blended learning.

Ketiga, ada hubungan positif antara motivasi berprestasi dan blended learning dengan hasil belajar matematika siswa SMP Terbuka 2 Tanjung Priok. Oleh karena itu dapat dikatakan bahwa hasil belajar Matematika siswa SMP Terbuka Tanjung Priok disokong oleh motivasi berprestasi bersama-sama dengan blended learning.

Dengan demikian, hasil belajar Matematika siswa SMP Terbuka 2 Tanjung Priok dapat ditingkatkan dengan melalui upaya meningkatkan motivasi berprestasi dan program belajar blended learning dengan secara sendiri-sendiri maupun secara bersamasama. Dengan kata lain, makin tinggi motivasi berprestasi siswa dan makin baik program belajar blended learning maka makin tinggi prestasi belajar matematika siswa.

\section{Saran}

Berdasarkan kesimpulan di atas, maka perlu kiranya disampaikan saran sebagai berikut. Pertama, kepada pihak sekolah maupun lembaga atau unit terkait yang bertanggung jawab dalam pengembangan dan pembinaan SMP Tebuka, agar selalu ada upaya merancang program pembelajaran yang memudahkan bagi siswa memahami dan mendalami matematika secara komprehensif, agar prestasi belajar matematika meningkat. Selain itu, pihak guru-guru yang mengajar matematika dan orang tua senantiasa memberikan semangat belajar melalui rangsangan-rangsangan berorientasi edukatif sehingga dapat meningkatkan hasil belajar siswa.

Kedua, kepada pemerintah pusat ataupun daerah dalam hal ini Direktorat Pembinaan SMP dan Bidang Pendidikan Dasar atau SMP di tingkat Propinsi atau Kabupaten Kota, dapat membantu fasilitas dan sarana bagi belajar bagi SMP Terbuka, sehingga mereka dapat melaksanakan pembelajaran yang menarik sehingga dapat meningkatkan hasil belajar mereka.

Ketiga, kepada Direktorat Pembinaan SMP Terbuka, program block grand untuk mengembangkan fasilitas pembelajaran yang berbasis Teknologi Informasi dan Komunikasi, dapat dilanjutkan kesekolahsekolah SMP Terbuka yang lain setara bertahap, sehingga pada akhirnya semua SMP Terbuka sudah dapat belajar melalu online learning, yang sekaligus meningkatpan pengetahuan dan kemampuan mereka 
dalam mengenal dan mengoperasikan komputer dan internet.

\section{DAFTAR PUSTAKA}

Beck, R.C. (1983). Motivation: Theories and principles. New Jersey: Prentice-Hall, Inc.

Bloom, B.S. (1956). Taxonomy of educational objective handbook I: The cognitive domain. New York: David McKay.

Church, M.A., Elliot, A.J., \& Gable, S.L. (2001). Perceptions of classroom environment, achievement goals, and achievement outcomes. Journal of Educational Psychology, 93, 43-54.

Elliot, A.J. \& Church, M.A.A. (2001). Hierarchical model of approach and avoidance achievement motivation, dalam "Motivating Humans-Psychology Group Web-Site" diakses dari situs http:// wabakimi. carleton.ca/ jlalonde/Group/ socialanxiety. html.
Gredler, M.E.B. (1991). Belajar dan membelajarkan. Jakarta: CV. Rajawali

Gagne, R.M \& Briggs, L.J. (1978). Principles of instructional design. New York: Holt Rinehart\&Winstons.

Ibrahim, N. (1997). Strategi pembelajaran di SMP Terbuka. Thesis. Jakarta, Pascasarjana IKIP Jakarta.

Ibrahim, N. (2001). Pengaruh tutoria radio interaktif tehadap hasil belajar fisika siswa SMP Terbuka. Disertasi. Jakarta, Pascasarjana Universitas Negeri Jakarta.

McGinnis, M. (2005). Building a successful blended learning strategy. Diakses dari situs http:// www.ltimagazine.com/ltimagazine/article/ articledeatil.jsp?id=167425 pada tanggal 3 Maret 2010.

Reigeluth, C.M. (1983). Instructional design theories and models: A new paradigm of instructional theory. New York: Routledge.

Thomas, L.G \& Brophy, J.E. (1990). Educational psychology. New York: Longman. 